\title{
PRESIDENTIAL ADVICE AND INFORMATION: POLICY AND PROGRAM FORMULATION
}

\author{
Norman C. Thomas*
}

The "Hickel letter" incident of May, 1970, occurring in the context of the movement of American forces into Cambodia and the campus crises that precipitated and followed the killing of four Kent State University students by National Guard troops, raised in dramatic fashion the questions that are asked about every national administration in time of trouble. "Who sees the President?" "To whom does he listen?" "Is the President isolated?" "What are his sources and means of obtaining information?" Although not nearly so widely publicized, similar and related questions concerned the members of two subcommittees of the House of Representatives as they conducted hearings in the Spring of 1970 on presidential advisory committees and on President Nixon's proposed Reorganization Plan No. 2 of 1970 , to restructure significantly the Executive Office of the President. ${ }^{1}$ These concerns reflect the general recognition among observers of and participants in high level national politics that responsive presidential policy leadership is as dependent upon the formal and informal processes whereby the President obtains advice and information as it is upon his personal characteristics such as political style and tactics. Academicians have understood the institutional as well as the personal dimension of presidential leadership for some time, ${ }^{2}$ but it often tends to be overlooked by sophisticated observers and is not recognized by the public. Undoubtedly, this condition exists because of the extent to which the mass media have personalized politics and, more importantly, because personal traits and characteristics have always offered simpler and more visible explanations of presidential behavior. It is easier for the analyst to develop and for the public to understand explanations that focus on the individual who occupies the White House than it is to wrestle with the complex questions of where ideas come from and how they are translated into policies that lead to operating programs of action.

\footnotetext{
- Professor of Political Science, Duke University; Author, Congress: Polittcs and Practice (Ig64); Rule 9: Poltics, Administration, and Civil Rights (1966).

${ }^{1}$ Hearings on Presidential Advisory Committees Before the Subcomm. of the Fouse Comm. on Government Operations, grst Cong., 2d Sess. (Mar. 12, 17, 19, 1970) [hereinafter cited as Presidential Aduisory Committees]; Hearings on Reorganization Plan No. 2 Before the Subcomm. of the Hotuse Comm. on Government Operations, 9rst Cong., 2d Sess. (Apr. 28, 30 \& May 5, 1970) [hercinafter cited as $R e$ organization Plan No. 2].

${ }^{2}$ See, e.g., P. ApplebY, Policy aNd AdManistration II3 (1949); Seligman, Developments in the Presidency and the Conception of Political Leadership, 20 AM. Socro. REv. 706 (1955); Scligman, Presidential Leadership: The Inner Circle and Institutionalization, 18 J. PoL. 410 (1956); J. BunNs, Presidential Governament ch. IV (1965); Cronin \& Greenberg, Introduction to The Presidential Advisorx Szstem xii-xx (T. Cronin \& S. Greenberg eds. 1969).

${ }^{3}$ Cf. Cronin \& Greenberg, supra note 2, at xic; Yarmolinsky, Ideas into Programs, The Public INTEREST, Winter I966, at 70 .
} 
In this paper I will examine the formal and informal advisory and informational devices that modern Presidents employ in the formulation of policies and programs." My primary concern is with information inputs to presidential decision-making processes and with the conversion of those inputs to policy choices. The questions that will guide the analysis include: (I) What are the President's major sources of information and advice? (2) What kinds of people tend to become presidential advisors? (3) What are the limitations of the various advisory mechanisms? (4) What are the advantages of the different mechanisms? (5) What kinds of relationships exist between the President and his advisory system? (6) What are the characteristics of a viable advisory system? (7) What trends and developments are emerging in the patterns of advising, informing, and assisting the President with respect to his policy-making responsibilities?

\section{Presidential Counselling: An Overview}

\section{A. Staffing the Presidency}

Since the late I930's, Presidents, their principal assistants, and students of the presidency have regarded as axiomatic the presidential dependence on advice and information and the need for assistance in securing and utilizing them. The Brownlow Committee Report of 1937, the Reorganization Act of $x 939$ which established the Executive Office of the President, the Employment Act of I946 which created the Council of Economic Advisers, the reports of the two Hoover Commissions in I949 and 1955, the development of an elaborate formal staff under President Eisenhowever, the use of informal and ad hoc study groups, task forces, and committees by Presidents Kennedy and Johnson, and, most recently, President Nixon's creation of the Domestic Council are manifestations of the continuing effort to respond to the presidential need for assistance. That effort is often referred to in governmental circles as "staffing" while academically it has been encompassed within the broader and more ambiguous term "institutionalization."

According to William D. Carey, a former Assistant Director of the Budget who spent 25 years with the Bureau of the Budget, staffing should assist the President with respect to policy analysis, communications, outreach, and command and control. ${ }^{5}$ In the process of policy and program formulation as distinguished from implementation, ${ }^{6}$ policy analysis, communication, and outreach are of more direct importance than

\footnotetext{
"Thomas E. Cronin, in his contribution to this symposium, explores the exchange system that the President relies upon for the implementation and monitoring of programs.

${ }^{5}$ Carey, Presidential Staffing in the Sixties and Seventies, 29 PUB. AD. Rev. 450 (I969).

- The distinction between formulation and implementation made in this symposium is one of convenience rather than theoretical conviction. It is not my intention to reinstitute the ancient politicsadministration dichotomy. There is quite obviously a continual overlapping of formulative and implementing actions in all policy areas as events move in parallel as well as in series with continual feedback from prior actions affecting future decisions. But there does exist a temporal sequence in presidential policy leadership and I have chosen to recognize it in order to deal more extensively with the subject and,
} 
the operational problems of command and control that lie at the center of policy implementation. Staffing for policy and program formulation has varied from the Roosevelt to the Nixon Administrations along a continuum of structural formality ranging from the elaborate staff arrangements favored by President Eisenhower to the free-wheeling administrative chaos that characterized the early years of the New Deal under President Roosevelt. ${ }^{7}$ The determination of an administration's position on that continuum is a matter of subjective judgment that rests on several factors: the President's desire to innovate; the frequency and duration of policy crises; the necessity and desire for secrecy in presidential decision-making; the President's leadership style; the President's personal relations with his immediate staff, his principal subordinates, and congressional leaders; the President's administrative orientation-his preference for systematized or random procedures, written memoranda or oral briefs, etc.; and the President's priority ranking among the great quantity of matters pressing on him for attention.

While I have not attempted to operationalize these factors so as to permit a quantitative measurement of recent presidential administrations, I will explore qualitatively their possible relationships with the degree of structural formality that might be anticipated in the presidency. It seems quite apparent that a President seeking to develop new policy departures will tend to prefer flexible staffing arrangements. This was the case with Presidents Roosevelt, Kennedy, and Johnson, all of whom were innovation-minded, but not with Eisenhower or Nixon, who both tended to favor improvement and refinement (some might say consolidation) of existing policies and programs. ${ }^{8}$ The President who seeks to change policies more than incrementally finds in helpful and necessary to obtain a steady flow of ideas, suggestions, and information from a wide range of sources outside as well as within the government. ${ }^{8}$ His emphasis is likely to be more on the scope and variety rather than the precision and detail of his policy intelligence. He is more apt to run the risk that his decisions may be based on less than a comprehensive analysis of the situation than to risk missing a promising new proposal that could lead to a breakthrough. However, the costs of the structural flexibility required by an innovative President can be substantial in terms of the lack of coordinated effort and the erosion of policy control. Activist Presidents have tolerated chaotic advisory

secondly, to distinguish more clearly between the types of advice and information sought, the sources of such knowledge, and the uses made of it in the principal stages of the presidential policy process.

' See R. Neustadt, Presidenttal Power (x960); A. Schlesinger, JR., The Coming of the New Deal chs. 32-33 (I959); K. Clark \& L. Legere, The President and the Management of National. SeCURITY (1969); Neustadt, Approaches to Staffing the Presidency: Notes on FDR and JFK, 57 Axr. Por. Scr. Rev. 855 (1963).

${ }^{8} \mathrm{I}$ am aware of the innovativeness of the Family Assistance Program that President Nixon proposed in I969. The major domestic policy orientation of the Nixon Administration is not activist, however. At most it can be characterized as mildly reformist or restorative.

' For a discussion of President Johnson's efforts to expand the sources of policy proposals beyond the traditional devices of agency submissions and clientele group suggestions see Leuchtenberg, The Genesis of the Great Society, The Reporter, April 2I, 1966, at 36-39; Thomas \& Wolman, The Presidency and Policy Formulation: The Task Force Device, 29 PUB. AD. REv. 459 (1969). 
processes and have often received sloppy if not shoddy advice. ${ }^{10}$ Policy crises can also affect staffing arrangements. A low incidence and short duration of crises tends to favor the growth of formalized staffing. As long as information can be obtained and processed routinely, formal arrangements can serve the President quite effectively. Crisis conditions, however, have a way of forcing the development of special temporary devices to deal with the particular situation. ${ }^{11}$ Information is needed quickly; there is no time for carefully prepared analyses embodied in position papers. Persons not normally in the formal policy-making structure may be needed for advice and consultation. The pace of events is so rapid that decisions must be reached without the usual process of checking and approval. These and similar considerations lead to flexible staffing arrangements. Of course, recurrent crises are now a fact of our national political life,--"emergencies in policy with politics as usual," Neustadt wrote over ten years ago $^{12}$-and to a degree they can be handled through predetermined routines. But to the extent that each crisis presents a unique threat to the nation and to the President it will call forth a special set of arrangements to deal with it. The more crises that arise, the more the President will require flexible devices to meet them.

Staffing arrangements are also a product of presidential personality and temperament. A President who has a penchant for secrecy and surprise, like Johnson or Roosevelt, finds flexible arrangements much more suitable than formal ones. Also, some Presidents-e.g., Roosevelt and Kennedy-are more free wheeling and less bureaucratically oriented than others in their approach to administrative tasks.

Finally, to the extent that national security policy matters intrude upon domestic politics formal staffing arrangements tend to be favored over informal. The handling of national security policy lends itself more readily to systematic intelligence gathering and evaluation and to structured decision-making than do domestic affairs. The opportunity for internal maneuvering and bargaining is greatly reduced in situations affecting national security. The need for consensus behind the President's course of action is a powerful stimulus to close ranks. This facilitates formalization. In addition, the sheer volume of information that must be processed in the national security policy realm requires a considerable amount of systematization. Also, since most Presidents find they must devote the bulk of their time and attention to national security policy, and some prefer to do so anyway, there are strong pressures toward formalized staffing.

It should be apparent, however, that not all of these factors work with the

${ }^{10} \mathrm{Cf}$. D. Moynthan, Maximum Feastble Misunderstanding (1969).

${ }^{21}$ The Cuban missile crisis of 1962 is an excellent case in point. President Kennedy dealt with the extremely grave challenge through the vehicle of a temporary "executive committee" consisting of key Cabinet and sub-cabinet officials, top-ranking military officers, and members of his staff. He did not reinstitute this body for any subsequent crisis. See A. Schrlesinger, JR., A Trousand Days chs. 30, 3I (1965); T. Sorensen, Kennedy ch. 24 (1965); E. Abei, The Missile Crisis (1966); Allison, Conceptual Models and the Cuban Missile Crisis, 63 Am. PoL. Scr. Rev. 689 (1969).

${ }^{12}$ R. NeustaDT, stapra note 7 , at IgI (I960). 
same intensity, and that they may work against each other in any given presidency. For example, Kennedy's strong foreign policy orientation, a formalizing influence, was apparently overcome by the steady flow of crises and by anti-formal personal preferences and traits. Thus, it is difficult to estimate precisely the degree of structural formality in recent administrations. It is possible on the basis of scholarly studies, however, to locate them in a rough ordering that gives some idea of relative formalization. ${ }^{13}$

\section{FIGURE I}

Formalization of Staffing Arrangements in Modern Presidential Administrations

\begin{tabular}{|c|c|c|c|c|c|}
\hline Roosevelt & Kennedy & Johnson & Truman & Nixon & Eisenhower \\
\hline $\begin{array}{l}\text { Highly } \\
\text { Informal }\end{array}$ & & \multicolumn{2}{|c|}{ Mixed } & & $\begin{array}{l}\text { Fighly } \\
\text { Formal }\end{array}$ \\
\hline
\end{tabular}

The intervals between the Administrations are proximate and some may quarrel with the position of the Johnson and Truman Administrations near the middle of the scale. Yet it can be said with some confidence that the Roosevelt and Eisenhower Administrations mark the opposite extremities of the continuum, that the Kennedy and Nixon Administrations are next in the degree of staffing informality and formality respectively, and that the Johnson and Truman Administrations do fall in the midsection with the former tending toward somewhat more informality.

The consequences of the level of staffing formalization are mixed. Both highly formal and extremely informal arrangements have accompanying costs and benefits for the President who adopts them. ${ }^{14}$ The principal advantage claimed for formally structured policy formulation lies in the comprehensive codification of decisions which results in increased presidential control of the bureaucracy and provides a basis for common understanding of policy goals and programs. It is also argued that a formal approach results in the more systematic, careful decisional processes that are essential to the management of large bureaucracies. The primary costs of formalization are asserted to be the loss of flexibility of action, premature closure of policy options, and the ultimate triumph of technique over purpose. It should be emphasized that no President will adopt a completely formal or informal approach to staffing. There is a considerable built-in tendency to formalization in the structures and routines of the component elements of the Executive Office, e.g., the budgetary process, that

\footnotetext{
${ }^{13}$ See the previously cited works of Neustadt, supra note 7, Clark \& Legere, stupra note 7, Thomas \& Wolman, stspra note 9; Neustadt's important articles on central clearance and presidential program planning, Presidency and Legislation: The Growth of Central Clearance, 48 AM. PoL. Scr. REv. 64r (1954), and Presidency and Legislation: Planning the President's Program, 49 Ax. PoL. Scr. REv. 980 (1955); Semple, Nixon I: Major Reshuffle at White House, New York Times, June I4, 1970, $\$ 4$, at I, col. I; Reorganization Plan No. 2, supra note $x$.

14 This discussion follows K. CLARK \& L. Legere, supra note 7, at 25-28, 217-18.
} 
cannot be abandoned for both practical and legal reasons. Likewise, there is such a continual flow of crises and new problems that no amount of systematic contingency planning or routinization can obviate the necessity for at least occasional resort to ad hoc policy guidance. But within fairly broad parameters a President may secure advice and information in a variety of ways. As noted above, much depends on the President's interests and style, but since it is not possible to measure let alone predict those qualities with any degree of confidence, I will focus the analysis that follows on the control of staffing for policy formulation through structural forms and institutionalized procedures.

\section{B. Information and Advisers in the Government Context}

Advising Presidents is complicated by the nature of the information process in government. That process has been characterized as "institutionalized selfdeception."15 This condition arises from two factors: the hierarchical structure of bureaucracy and the adversary nature of American politics. The men in the higher echelons require information-facts and arguments-to defend themselves against attack. Their subordinates and their staffs undertake to provide it to them. In order to serve their chiefs and to protect themselves, advisers and information sources inside the government tend to make their presentations in the most favorable light possible. The result is that "a kind of propitiatory optimism creeps into government reports"16 and "what is taken to be true, therefore, is what it is politically desirable to believe."17 It is incumbent on top officials, Frankel concludes, to recognize this flaw in governmental communications and to develop corrective instruments that will introduce a measure of skepticism to the decision-making process sufficient to insure more balanced judgments. One of the most effective and widely utilized correctives is seeking advice from outsiders, particularly from the so-called "experts." This practice also has its limitations, however.

Outside advisers, especially intellectuals and/or technical experts, encounter substantial difficulties in attempting to challenge the criteria that are the basis of existing policies. True, they bring to their task prestige, extensive information, intensive experience, and perspectives grounded more in theory and first principles than pragmatic compromises with perceived reality. But these assets are fragile and are accompanied by liabilities. Laski has warned that in the political realm, expertise runs the danger of sacrificing "the insight of common sense to the intensity of experience."18 Since experts often lack humility and broad perspective, Laski argues that they can only make a valuable contribution to government if they can manage to

\footnotetext{
${ }^{18}$ C. Franket, High ON FogGy Bottom 8o (I969). Frankel, a distinguished philosopher, served from July 1965, until December 1967 , as Assistant Secretary of State for Cultural Affairs. This discussion draws upon his incisive account of his bureaucratic experience.

${ }^{10} \mathrm{Id}$. at 83 .

${ }^{17} \mathrm{Id}$. at 88 .

${ }^{18}$ Laski, The Limitations of the Expert, in The INTELlecroals 167 (G. De Huszer ed. 1960).
} 
relate their judgments to the values and aspirations of the public. Also, experts should take care not to oversell their advice. This is perhaps particularly applicable to social scientists whose theories and understanding of human behavior are limitedin spite of extensive information and sophisticated research. Yet, in an effort not to appear incompetent when asked for advice, they will often make recommendations that are either unrealistic or politically infeasible when the wiser course of action would be merely to suggest what common sense dictates. Kissinger, in a perceptive discussion, ${ }^{19}$ asserts that the central problem that the intellectual faces when called upon for advice is that his contribution is invoked and utilized in terms of bureaucratically determined criteria. He thus finds that he may be providing information that becomes the basis for endorsing and legitimizing existing policies rather than serving as the basis for judgment regarding the efficacy of those and alternative policies. In addition, the intellectual must be careful not to formulate his contribution so abstractly as to destroy its value to the political leaders who requested it. The challenge to the intellectual whose expertise is invoked is, therefore, to reconcile "two loyalties: to the organization that employs him and to values which transcend the bureaucratic framework and provide his basic motivation."20 Most of all, the intellectual who serves the government must retain his independence and his disinterestedness. It is no easy task to accomplish, but the effort must be made as long as the advice of intellectuals and experts is essential to effective leadership in policy formulation.

The information process in government is also complicated in its efforts to incorporate expertise effectively by the extensive reliance placed upon committees as vehicles for coordinating advice, synthesizing information, and framing proposals. Kissinger states that reliance on committees arises from the lack of substantive competence by high-level political executives. ${ }^{21}$ As policy is identified with committee consensus it loses any sense of direction and becomes a matter of adjustment to the lowest common denominator. Committees, asserts Kissinger, emphasize conversation and fluency rather than reflectiveness and creativeness. They tend to suppress disagreement in the quest for consensus which most often favors the familiarity of the status quo. In their normal functioning, committees, whether they are composed of government officials or outside experts, are subject to substantial weaknesses. They cannot provide top leaders with the sense of purpose that will enable those officials to make effective use of the committee system. So far it has not been possible to develop a presidential advisory and information system that overcomes the limitations of governmental information processes, including the defects of committees. This analysis of presidential staffing devices will consider their potential for resolving such problems.

\footnotetext{
${ }^{10} \mathrm{H}$. Kissinger, The Necesstix for Choice ch. 8 (I960).

${ }^{20}$ Id. at 353 .

${ }^{22}$ Id. at 343. See his discussion of committees and their defects, id. at 344-47.
} 
The Vartous Advisory Mechanisms

The President obtains advice and information from the presidency itself, the executive branch, Congress, and the public. The utilization and evaluation of this "intelligence" is accomplished through four principal mechanisms: the Cabinet and its appurtenant committees, the Office of Management and Budget, the White House staff, and a variety of presidential advisory groups including task forces, councils, commissions, conferences, and committees. ${ }^{22}$ These advisory devices are not arrayed in a neat series of concentric institutional rings around the President. There is often overlap between the channels of the devices so that information flows from one to the other or it may be simultaneously processed by two or more of them. The utilization of specific advisory mechanisms is in part a function of their proximity to the President, but it is also determined by his relationships with individual advisers and their access to him. Although this analysis of advisory mechanisms has an institutional focus, it is undertaken with a recognition of the importance of individual interaction between the President and his advisers.

\section{A. The Cabinet}

The advent of a new national administration is always heralded by extensive speculation concerning the composition of the Cabinet. This speculation usually centers on leading members of the President's party, but it takes into consideration certain criteria of appointment designed to give the Cabinet a broadly representative character. For example, the Secretary of the Interior is traditionally a Westerner, Agriculture goes to a farm state figure, the Attorney General must be a lawyer, and Commerce and Treasury are usually filled by men from the business community. Not infrequently the President-elect has announced his determination to utilize the collective talents of his Cabinet, which of course will include "the best men the nation has to offer," in the conduct of his administration. The Cabinet, it is promised, will become a meaningful instrument of leadership and not a ceremonial organ with little functional value. By implication the previous administration failed to utilize the Cabinet's great potential as an advisory council for high-level policy formulation. With equally predictable frequency, the new President finds after no more than a few months in office that the Cabinet is hardly a suitable vehicle for collective decision-making. Its value, as a collectivity, is more symbolic than operational; as an institutional embodiment of the representational scope of the administration rather than an instrument of collective choice.

The problem that Presidents encounter when they attempt to utilize the Cabinet is that it is a far more suitable means of consolidating and extending political strength than of advising with respect to policy development. It is an aggregation

\footnotetext{
${ }^{28}$ This typology of advisory mechanisms follows that suggested by Cronin \& Greenberg, supra note 2, at xvii-xviii.
} 
of highest level presidential advisers, but not a viable high-level advisory group. This condition is a consequence and reflection of the "pluralistic conditions of departmental growth and of Cabinet appointment."23 Cabinet departments developed over time to perform a variety of functions in response to the felt needs of many divergent groups. This pattern of growth encouraged the departments to act more or less independently of each other. The selection of Cabinet members on the basis of geographic and clientele interests encourages in Cabinet members a particularistic loyalty to their subordinates and to their clientele groups that competes with loyalty to the President. This conflict of loyalties works against the formation of any informal sense of mutual responsibility. But without a "sense of corporate unity and common purpose," ${ }^{, 24}$ the Cabinet's potential as an advisory body cannot be realized.

The President can, and frequently does attempt to build support through individual Cabinet members and their departments. But even this use of the Cabinet is limited by the conflict of loyalties. To the extent that Presidents choose Cabinet members who will be unbending in their fealty to him, they risk weakening the supportive potential of the appointments. The departmental pressures that impinge on Cabinet members are so strong, however, that they "may make even a personal supporter act as the President's 'natural enemy' when he heads a major department."25 The resignation of Health, Education and Welfare Secretary Robert Finch in May, 1970 provides a contemporary illustration of this old problem. A close personal friend and long-time political associate of President Nixon, Finch experienced great difficulty in reconciling his intense personal loyalty to the President with the expectations of the HEW bureaucracy and the demands of its clientele. His seventeen month tenure as Secretary was marked by his refusal to exploit his relationship with the President on behalf of his departmental constituency and that constituency's consequent disenchantment with him. When Finch left the Cabinet it was to assume a position on the White House staff as a counsellor to the President that was more compatible with their special relationship.

The Finch case raises the question of the degree to which it is possible for Cabinet members to be the President's men. ${ }^{26}$ While no President can tolerate a Cabinet in which all members regularly choose departmental over presidential interests, it is also true that unquestioning loyalty to the President is equally dysfunctional. What is called for is a Cabinet-presidential relationship that is "at once highly autonomous and deeply responsive."27

The unsuitability of the Cabinet as an advisory mechanism does not mean, however, that the President is not dependent on his department heads for advice. But

\footnotetext{
${ }^{23}$ R. Fenno, The Prestient's Cabinet i3I (I959).

24 Id. at 132 .

${ }^{28}$ D. Truman, The Governmental Process 406 (x95I).

${ }^{26}$ Cf. M. Bundy, The Strength of Government 37-40 (1968).

${ }^{27}$ Id. at 38 . See also T. Sorensen, Decision-Makine in THE White House 68-yo (1963).
} 
the advice and political assistance which Cabinet members can provide must come from them as individual political actors of considerable standing. As the head of a large bureaucracy with substantial information gathering and evaluating capabilities, with at least some independent sources of power, the Cabinet member has resources that are valuable to the President. They can be utilized in various ways. Cabinet members are usually consulted extensively regarding the development of presidential policies in their areas of activity. They participate in the development of legislative proposals for their departments ${ }^{28}$ and in deliberations that lead to the formulation of the President's legislative proposals. Frequently Cabinet members serve on interdepartmental committees and task forces that formulate policies and resolve differences between agencies. Also, depending on their departments, Cabinet members serve on either the National Security Council or the newly established Domestic Council.29

There is, then, a substantial amount of unified presidential policy control over departments and agencies, but it is not achieved through the Cabinet. It arises through the use of other instruments and through direct relationships between the President and individual Cabinet members. In this latter regard, the Cabinet official often acts as a broker between the President and his staff and the bureaucracy and its clientele. Occasionally a Cabinet member may become a close confidant of the President on policy matters that range beyond the jurisdiction of his own department. In such instances, mutual respect and attraction permit the Cabinet member to be more than a formal adviser. The cases of Attorneys General Robert Kennedy in his brother's Administration and John Mitchell in the Nixon Administration illustrate this type of relationship. In all cases, however, a Cabinet member is only as important as the President wants him to be. The influential men in the Cabinet will shift depending on presidential preferences and values and external circumstances.

In the final analysis, it is necessary to look at devices below and beyond the Cabinet to understand fully the dynamics of presidential intelligence for policy formulation. Cabinet members are major participants in the policy-making process in their roles as heads of executive departments and by virtue of individual personal and political resources and not as members of a group of top level advisers. But the Cabinet member is more than a presidential staff resource or personal adviser. ${ }^{30}$ $\mathrm{He}$ is the principal political executive in his particular policy arena. In this capacity he often speaks for the administration. Neustadt's remarks on the role of the Secretary of State are particularly instructive regarding the situation of the Cabinet member:

The Secretary has work of his own, resources of his own, vistas of his own. He is in business under his own name and in his name powers are exercised, decisions

\footnotetext{
${ }^{38}$ See Neustadt, Presidency and Legislation: Planning the President's Program, stpra note ${ }_{33}$; Neustadt, Presidency and Legislation: The Growth of Central Clearance, supra note I3.

${ }^{20}$ See the discussion at 554 infra.

${ }^{30}$ See Testimony of Richard Neustadt Before the Senate Subcommittee on National Security Staffing and Operations, in The PREsidenCY 5 II (A. Wildavsky ed. 1969).
} 
taken. Therefore he can press his personal authority, his own opinion, his adviser's role, wherever he sees fit across the whole contemporary reach of foreign relations ... his status and the tasks of his Department give him every right to raise his voice where, when and as he chooses. ${ }^{31}$

The Cabinet member draws much of his advisory strength from his departmental responsibilities; yet he cannot devote himself too extensively to running his department, else important policy choices will be made with little input from him.

The inefficacy of the Cabinet as a formal advisory mechanism and as a policymaking body does not obviate the need for collective action at some point in the process. Differences in perspective and objectives are bound to exist between agencies. Somewhere, not too far removed from the President, there must be a means of identifying alternatives, clarifying goals, and settling upon compatible courses of action. In short, policy coordination is necessary. Given the phenomena of departmentalism and of social and political pluralism, that coordination can only be secured through committees or through routinized procedures. It cannot be obtained by presidential fiat.

Cabinet-level committees for policy-making and policy coordination include those appointed to deal with a specific subject or problem, such as the Cabinet committees on economic policy and on environmental quality, and formal policy councils like the National Security Council (NSC) that are established by law or executive order and that operate with sizeable staff support. The most widely utilized means of securing coordination, however, is the interagency committee which generally operates at the sub-cabinet and agency head level.

Cabinet committees can be an effective means of handling a specific situation or policy problem. They can focus attention on it quickly and have flexibility in developing situations. But they are limited by other demands and claims made on their members. If Cabinet committees are provided with supportive staffs of significant size they quickly tend to become routinized operations and to lose the sense of urgency and the flexibility that justified their initial establishment. Cabinet committees that acquire permanent status tend to lose their high initial visibility and also their capacity to hold the attention of their members. They become one of many groups operating in the presidential arena. The committee that President Nixon established to facilitate school desegregation illustrates the problems encountered by a continuing Cabinet-level committee. The committee was chaired by the Vice President and included the Attorney General, the Secretary of HEW, and a number of subordinate officials. Because desegregation involves unsettled questions of constitutional interpretation and is a highly sensitive issue, the committee has not been able to develop a uniform national policy. Presidential statements on the subject have reflected the differing approaches of the Justice Department and HEW. Continuing controversy has forced the committee into the background.

\footnotetext{
${ }^{31}$ Id. at $522-23$.
} 
B. The National Security Council

An important institutional participant in the presidential advisory system is the National Security Council, a body which "constitutes the most ambitious effort yet made to coordinate policy on the Cabinet level."32 Since its establishment the NSC has been both central and peripheral to the formulation of national security policy. A review of the uses that Presidents have made of the NSC reveals the alternative ways of allocating responsibility for policy planning and coordination in this crucial area.

President Truman saw the NSC, which was established by the National Security

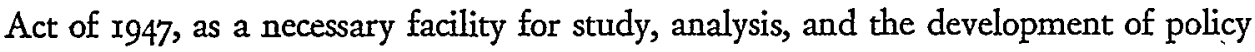
recommendations. Truman did not, however, regard it as a policy-making body. He was concerned lest the NSC encroach on his constitutional powers and thus he did not meet with it until the Korean war began. Even with its increased activity and status after that point, the NSC was no more than a convenient staffing mechanism with a limited policy-making role.

In sharp contrast, President Eisenhower expanded the NSC into a comprehensive policy system. He regarded the council as a top level forum for vigorous discussion of carefully prepared policy papers. These NSC discussions contained statements of divergent interpretations and approaches and ultimately produced resolutions of the issues. The NSC was, in Eisenhower's view, a corporate body of advisers rather than a group of departmental and agency spokesmen. He chaired NSC meetings and led discussions of papers prepared by the Planning Board, one of the two staff arms of the Council. The other staff unit, the Operations Coordinating Board, concerned itself with problems of policy implementation. After a subject had been raised for NSC consideration by anyone from the President on down in the system, an analysis would be conducted under the direction of the Planning Board and involving the agency with the major interest in it. Eventually a policy paper would come before the council for discussion and action. Once approved, NSC policy actions were sent to the departments and agencies for execution under the direction of the Operations Coordinating Board. The process has been described as a "policy hill" with the NSC at the summit and policies moving up the formulative side through the Planning Board and down the implementation side through the Operations Coordinating Board to the departments. ${ }^{33}$ The NSC also dealt with current policy matters, although smaller groups of officials usually handled important issues.

President Eisenhower's NSC staff system imposed a comprehensive framework of order on all aspects of national security affairs. Its defenders argued that it insured that the President would receive all relevant information and points of view, that it

\footnotetext{
${ }^{32}$ Hammond, The National Security Council as a Device for Interdepartmental Coordination: An Interpretation and Appraisal, 54 AM. PoL. Scr. REv. 899 (1960). See also Falk, The National Security Council Under Truman, Eisenhower and Kennedy, 79 PoL. Scr. Q. 403 (1964); K. Clark \& L. Legere, supra note 7, at chs. 4-5. This discussion draws upon these sources.

${ }^{33}$ See Cutler, The Development of the National Security Council, 34 Foreign Afratrs 442 (1956). See also R. CUTLER, No TIME FOR Rest (1966). Cutler was President Eisenhower's Special Assistant for National Security Affairs.
} 
provided a reservoir of policy guidance, and that it afforded rational coordination of policy formulation and execution. Its critics charged that the system was so ponderous that it was incapable of responding effectively to emergencies or of developing new policy departures. In was asserted that the NSC system rigidified an incremental approach in a policy arena where flexibility was of great value. Furthermore, the critics claimed, the system purchased consensus at the price of ambiguity. Differences were said to be papered over with vague policy statements that had no value as guides to action.

The alleged defects of President Eisenhower's NSC system were highlighted in a senatorial inquiry conducted by Senator Henry M. Jackson (D-Wash.) during x 960 and $x 96 .^{34}$ The Jackson subcommittee made a series of proposals that would have "deinstitutionalized" the system. It recommended that the Council be a smaller group, limited in membership to top officials and meeting only to advise on critical issues and problems. The support staffs would be abolished and their functions reassigned. Finally, the subcommittee suggested that the Secretary of State take the lead in formulating national security policy and that coordination of policy implementation be accomplished by an action officer or an informal interdepartmental committee.

President Kennedy, acting along the lines proposed by the Jackson committee, proceeded to dismantle most of the Eisenhower NSC system. All that remained was the statutory council consisting of the President, Vice President, the Secretaries of State and Defense, and the Director of the Office of Emergency Planning, and a small staff headed by McGeorge Bundy, the Special Assistant for National Security Affairs. The Council was but one of many ways of solving problems and President Kennedy consulted its members more often individually than collectively. The NSC staff became involved in various activities and was a major source of information for the President. It worked closely with the bureaucracy, the Bureau of the Budget, and the Office of Science and Technology. Its principal task was to identify and manage issues. When it became apparent that the State Department was unable to assume the major responsibility for initiating and coordinating national security policy, the NSC staff assumed much of that important role.

The NSC itself was primarily used to consider long term policy problems that could be dealt with through planning. The NSC staff worked more directly for the President than for the Council. It concentrated on the action oriented processes that President Kennedy's approach to foreign affairs required. The Eisenhower distinction between planning and operations was abolished in favor of a commitment to action with policy serving as the rationale.

The abrupt transition from the Kennedy to the Johnson Administration was marked by the new President's desire to minimize the shock of the assassination.

\footnotetext{
sh Subcomm. on Nattonal Policx Machinery of the Senate Comm. on Government Operations, 86th Cong., 2d Sess., Organizing for National Security (Comm. Print 1960).
} 
Gradually a distinctive Johnson pattern emerged. It was characterized by the President's reduced dependence on the national security staff in dealing with the bureaucracy and by increased reliance on the State Department for policy coordination. The NSC met fairly often, but rarely to consider major current issues. More important to presidential policy formulation were weekly luncheon meetings, held on Tuesdays, of the President and selected top officials. These informal gatherings served as vehicles for making key decisions, receiving advice, and establishing policy guidance. The informality of the meetings permitted an extensive interchange of viewpoints and stimulated a flow of information, but they were defective in that items often arose without advance staff work and no record of decisions was kept.

The Johnson presidency was one in which the President received a heavy flow of information through personal contacts and written memoranda. His responses, usually transmitted verbally by the Special Assistant for National Security or the NSC staff, served as guidelines for the bureaucracy. But there was no mechanism for locating issues and centralizing their management. The President disposed of most issues on the basis of memoranda processed by the Special Assistant. Decisions were made after discussions with a wide range of individuals in and outside of the government. There was, however, "no predictable pattern to such consultation .... At the end a decision emerged."35

In order to reduce the need for the NSC staff to function as an ad hoc interdepartmental coordinator, President Johnson delegated to the Secretary of State, in National Security Action Memorandum 34I of March I966, responsibility for "over-all direction, coordination, and supervision of interdepartmental activities." The vehicles for accomplishing this mission were the Senior Interdepartmental Group (SIG) headed by the Undersecretary of State and Interdepartmental Regional Groups (IRG's) headed by assistant secretaries of state. The operational consequences of this system were not as intended. Whenever the President or the NSC staff assumed control, as they did with respect to most critical issues, "the existence of the system was of little significance."36

President Johnson's approach to national security policy had two distinguished characteristics-informality and heavy reliance on the NSC staff under the direction of the Special Assistant. The NSC staff was not actively involved in policy initiation, however. What it did was act as an intermediary and brokerage agent for the President, offering advice and providing support when required. The President retained much direct power over national security matters in his own hands, leaving largely to chance and his personal resources the formulation of coherent and rationally interrelated policies.

It is somewhat premature to speak with certainty about the Nixon Administration's arrangements for managing national security policy. President Nixon appears

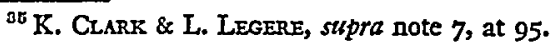

${ }^{80} 1 d$. at 103 .
} 
to have concluded that a substantial National Security Council staff under the direction of his Special Assistant, Henry Kissinger, and the reestablishment of the formal NSC system are both necessary. The Kissinger staff, considerably expanded and more formalized than its predecessors, plays a major role in coordinating interdepartmental policy planning. The NSC has been reactivated as "the principal forum for presidential consideration of foreign policy issues." ${ }^{\text {"37 }}$ The NSC met 37 times in 1969 and considered over 20 major problems. It operates in a manner similar to the Eisenhower NSC only without the formal staft units. Initial policy analyses are prepared by Interdepartmental Groups chaired by an assistant secretary of state. (These resemble the IRG's of the Johnson Administration.) Then an interagency review group of senior officials, which is chaired by Kissinger, examines the papers "to insure that the issues, options, and views are presented fully and fairly."38 Finally, the matter under consideration is presented to the President and the NSC.

Nixon's NSC system seeks to involve all relevant agencies in a process that insures that the President and the Council have all the available pertinent information. It obtains a measure of flexibility through special interagency groups, such as the Verification Panel in the area of strategic arms limitation and the Vietnam Special Studies Group. It makes provision for crisis planning and management through a special group of high officials, the Washington Special Actions Group.

The Nixon NSC system combines White House and departmentally centered control of policy formulation through use of both a sizeable NSC staff and interagency groups. It relies on systematic formal procedures but seeks to retain flexibility through special committees. Most significantly, according to the President, it is built upon a realistic appraisal of the tasks that it faces. ${ }^{30}$

\section{The Domestic Council}

As Wildavsky has observed, there are two presidencies, one concerned with national security policy, the other with domestic affairs. ${ }^{40}$ Substantial differences distinguish the two policy realms. In national security policy, events often move at a rapid pace with potentially grave consequences. Very little that happens can be dismissed as inconsequential and actions may be irreversible once taken. In domestic affairs, policy decisions are usually incremental adjustments in previous courses of action. Major policy changes occur only infrequently and then only after prolonged pressure and deliberations or in periods of crisis. Most domestic policy decisions are reversible; if they fail to meet the pragmatic test of results, something else will be tried. Another difference involves presidential control over

\footnotetext{
${ }^{37}$ Report by President Nixon to the Congress, U.S. Foreign Policy for the I970's: A New Strategy for Peace, in 116 Cong. Rec. Hg27 (daily ed. Feb. 18, 1970) [hereinafter cited as Report by President Nixon].

${ }^{88} I d$.

${ }^{80} \mathrm{Id}$. at $\mathrm{H}_{928}$.

${ }^{\circ}$ Wildavsky, The Two Presidencies, Trans-Acrion, December, 1966, at 7. This discussion draws on Wildavsky's excellent analysis.
} 
policy. As a matter of constitutional and practical necessity Presidents have greater discretion in national security matters. There are fewer rivals for policy control and the ability of those rivals to obtain and use information is much less than in domestic affairs. The range of options and competitors is much broader in the domestic realm where interest groups and Congress possess greater capacity to bargain with the President. Wildavsky calculates that in the period I948-64, positive congressional responses to presidential initiatives were almost twice as great in national security matters as in domestic affairs. ${ }^{41}$

The differences between the two policy realms have resulted in contrasting staffing patterns. National security policy formulation has transpired with the benefit of the elaborate intelligence capabilities of the Central Intelligence Agency and the armed services and with the support of the NSC and its staff. There has been no comparable formalization of structure and process in the domestic arena. Coordination of policy formulation has been a responsibility of many agents: the Bureau of the Budget, the Council of Economic Advisers, the Office of Science and Technology, and more recently, the councils on rural and urban affairs, as well as devices such as interagency task forces, the concept of a lead agency, and reliance on individual presidential assistants. There has been an informal and often unsystematic approach to policy formulation as compared with the national security policy arena. To the extent that there has been a coordinating force, it has been provided by the budget bureau. But the Bureau was never intended to function as a top level policy council that considered proposals for action after careful staffing had been completed. Rather, it was a staff agency with about 500 career professionals that cleared legislation drafted in the bureaucracy, analyzed proposals emanating from the departments, agencies, and other sources, and prepared the budget. All this was done with a view to maintaining the integrity of the President's overall program.

The pattern of domestic policy coordination has varied between administrations. For example, President Johnson utilized a small staff headed by Joseph A. Califano, a presidential assistant. President Kennedy assigned responsibility to a group of his White House staff aides with special assignments to his brother. Under President Eisenhower, Sherman Adams, acting in the manner of a military chief of staff, personally directed the process of domestic policy coordination. President Nixon, after a year in office and on recommendation from his Advisory Council on Executive Organization, established the Domestic Council through Reorganization Plan No. 2 of I970. The Domestic Council is composed of the President, the Vice President, the Attorney General, the Secretaries of Agriculture, Commerce, HEW, HUD, Interior, Labor, Transportation, and Treasury, and other officials as may be deemed appropriate on an ad hoc basis. The Council is to have a staff of professional

\footnotetext{
"1 Id. at 8 .
} 
experts $^{42}$ and is headed by a presidential assistant whom the President designates as its executive director.

At this writing, the Domestic Council is still establishing its procedures and recruiting its staff. The pattern of its operations is not sufficiently clear to permit a description, let alone an analysis, to be made. However, the rationale for the Council and the Administration's expectations for it were made quite explicit in the House hearings on the reorganization plan. ${ }^{43}$ According to Roy L. Ash, the chairman of the Advisory Council on Executive Reorganization, ${ }^{44}$ the major organizational premise was that presidential staff functions for policy and program formulation should be separated from those for program implementation and administration. This reaffirmation of the old politics-administration dichotomy, ${ }^{45}$ which academicians had thoroughly discredited by the early $195^{\circ}{ }^{4},{ }^{46}$ rested on the belief that it was "unsound" to have the same organization perform both functions because different kinds of information, skills, and attitudes are sequired for each and because policy formulation requires a longer time perspective and is less subject to daily pressures than implementation is. ${ }^{47}$ Such a formal separation of functions characterized the NSC system under President Eisenhower, but it had not previously been employed in presidential staffing for domestic affairs. Its effectiveness remains to be demonstrated. It does recognize the increased necessity for effective program evaluation and the complexities of program implementation.

The Ash commission envisioned the Domestic Council as "a way to bring together under one roof many, but not necessarily all, of the sources for developing domestic policy." ${ }^{38}$ It is intended to provide a more effective means than reliance on interagency task forces and informal contact by the White House staff of bringing necessary information and opinions to the President and of resolving interagency disputes. The Domestic Council formalizes previous arrangements which, according to the Ash commission, were random and haphazard. The staff will gather information, analyze issues, and present the Council with opposing lines of reasoning.

\footnotetext{
${ }^{\star 2}$ At this writing the staff consists mostly of Republican political activists rather than social scientists and other specialists.

${ }^{\star 3}$ Reorganization Plan No. 2, supra note $x$.

"The council was established on April 5, r969. Mr. Ash, the President of Litton Industries, served as its only chairman. It has commonly been referred to as the Ash Commission.

${ }^{4}$ The development of the analytical distinction between politics and administration is attributed to Woodrow Wilson and Frank J. Goodnow. See Wilson, The Study of Administration, 2 PoL. Scr. Q. 197 (I897); F. Goodnow, Politics AND Administration (I900). The relationship of the dichotomy to American administrative scholarship is carefully explored in D. Waldo, The Adomistrative State ch. 7 (1948).

${ }^{B}$ See Friedrich, Public Policy and the Nature of Administrative Responsibility, in I Public Poricx (C. Friedrich ed. 1950); Kingsley, Political Ends and Administrative Means, 5 PuB. Ad. Rev. 375 (1943); W. Anderson, Resenrch in Public Administration ro6 (1945); P. Aprleby, supta note 2; Long, Power and Administration, 9 PUB. AD. Rev. 257 (1949); Long, Bureaucracy and Constitutionalism, 46 Ax. Por. Scr. Rev. 808 (1952); Long, Public Policy and Administration: The Goals of Rationality and Responsibility, 55 Pub. Ad. Rev. 22 (1954).

${ }^{47}$ See the testimony of Roy L. Ash, Reorganization Plan No. 2, supra note $\mathrm{I}$, at 9-10.

${ }^{48} I d$. at Io.
} 
The task of the staff will be to make certain that policy alternatives have been fully presented so that the President and the Council can make informed, rational choices. It is anticipated that the President and the Council will act with a "common data base" developed by the staff. ${ }^{49}$ The Ash commission realized that Presidents will vary in their utilization of the Domestic Council. Its expectation was, however, that the Council will prove to be a useful managerial tool that increases the President's control over policy formulation and reduces somewhat the time required to achieve it.

The establishment of a domestic analogue to the NSC raises several questions. Although the Domestic Council staff is supposedly to refrain from reconciling any issues in its analyses, is it realistic to expect that the staff will not have a major substantive impact on policy? Such an impact can perhaps be minimized if recruitment is on professional grounds. But the pressures to insist on political criteria will be great if not overpowering. The establishment of a technical career staff comparable to that of the former Bureau of the Budget seems unlikely. One of the advantages of the Bureau was its devotion to the needs of the presidency. This was made possible, at least in part, by its separation from the political pressures of the White House. The Domestic Council-if it is to be the high-level forum for discussion, debate, and ultimate policy determination that its creators envision-will operate in closer proximity to the President. It will necessarily have a highly political staff. Can this staff provide a continuing institutional memory for domestic affairs?

A second set of questions pertain to the Domestic Council's relationships with other presidential staff units, with the bureaucracy, and with Congress. At the reorganization hearings, Representative Chet Holifield (D-Calif.) argued that the Council would become a barrier between the President and the new Office of Management and Budget (OMB). This would downgrade the OMB, Holifield reasoned, since the policy functions formerly exercised by the budget bureau would be performed by the Council staff. Furthermore, Holifield feared, that staff will be unavailable to Congress and yet be able to affect the decisions of the OMB. ${ }^{50}$ The question of congressional-Domestic Council staff relations remains to be determined. The role of the OMB in policy formulation does appear likely to be substantially reduced. The OMB will no longer participate in formulating legislative proposals and following them through. The useful feedback of program results and knowledge of program defects that enabled the budget bureau's program divisions to help the bureaucracy develop amendments to existing legislation and to formulate new legislative proposals will be channeled to a different policy staff. Raymond Saulnier, who served as chairman of the Council of Economic Advisers (CEA) during the Eisenhower Administration, raised objections at the hearings to the absence of the Budget Director and the Chairman of the CEA from the Council's statutory mem-

\footnotetext{
${ }^{10} \mathrm{Id}$. at 55 .
}

${ }^{50}$ Id. at 43 . 
bership. ${ }^{51} \mathrm{He}$ argued that this would deprive the Domestic Council of the "intimate knowledge of budget resources and demands" and the CEA's special competence in economic matters. He recommended that the CEA be assigned responsibility for staffing Domestic Council agenda items in its area. Whether the importance of the OBM, CEA, and other staff units will be lessened is an unanswered question. Their status may be jeopardized by the new arrangement, but it is too early to make such a judgment.

Finally, it is unclear how the existence of the Domestic Council will affect interagency relations and agency access to the President. The department heads will undoubtedly have access to him through the Council and also directly as in the past. But their subordinates will not have these points of contact. Agency heads and subcabinet officers will have to deal with the Council staff on matters involving policy formulation and with the $\mathrm{OMB}$ on matters of budget and policy implementation. To the extent that the OMB retains its former policy formulation roles, there will be duplication of effort (with the risk of considerable confusion) and the rationale for the reorganization will be defeated. There is also a question regarding access to the White House. In the Johnson and Kennedy Administrations, presidential assistants served as points of contact for agencies and interest groups and acted as brokers between the White House, the bureaucracy, Congress, and the attentive public. For example, Douglass Cater was President Johnson's liaison man for educational policy. Even after two years of the Nixon presidency, there is still (in early 1971) great uncertainty regarding the points of contact. The Domestic Council may increase rather than reduce the communication gap between the White House and the bureaucracy, especially below the Cabinet level. The Council and its staff may isolate the President rather than bring him closer to the operational problems of domestic politics as intended.

The Domestic Council is, then, a major but uncertain factor in presidential policy formulation. Ideally it will prove to be an effective staffing arrangement that permits the administration to arrive at the "best solution after weighing carefully all viable choices." ${ }^{\text {2 }}$ On the other hand, it could become a rigidified policy control structure that impedes initiative, blocks alternatives, stifles originality, and is incapable of quick, flexible responses. ${ }^{53}$ The best guess is that its performance will fall between these two stools..$^{54}$

\section{Office of Management and Budget}

Since presidential-bureaucratic relations through the instrumentality of the former

\footnotetext{
${ }^{51}$ Id. at 32-34. Supporters of the reorganization plan responded that the Chairman of the CEA and the Budget Director would be included on the Council at the President's discretion.

52 House Comag. on Governarent Operations, Disapproving Reorganization Plan No. 2 of ig7o, H.R. Rep. No. ro66, 9rst Cong., 2d Sess. 23 ( 1970 ).

${ }^{53}$ Id. at $2 \mathrm{I}$.

${ }^{54}$ Cf. Carey, Reorganization Plan No. 2: Remarks by William D. Carey, 30 PuB. Av. Rev. 631 (I970).
} 
Bureau of the Budget (BOB) are the subject of another paper in this symposium, ${ }^{55}$ I will not dwell at length on the role of this major presidential staff unit in policy formulation. As every student of American government learns in the introductory course, $\mathrm{BOB}$ did far more than prepare the annual presidential budget. It had a major responsibility for coordinating and safeguarding the integrity of the President's overall program. ${ }^{58}$ It had an impact on policy formulation through the preparation of budget requests for departments and agencies, the clearance of all views expressed by federal agencies on pending legislation, review and evaluation of legislative proposals originating in the bureaucracy, and coordination of the process of developing and preparing presidential legislative proposals. In performing its duties, the budget bureau worked closely with the bureaucracy. It developed a professional expertise of its own based on substantive knowledge acquired over time and committed to serving the President. In recent years, BOB played a key role in staffing and organizing the work of presidential advisory groups. Bureau officials served on advisory committees or their staffs, the Bureau analyzed advisory committee reports and recommendations, it participated in high-level consideration of those reports, and it was the mechanism for linking committee proposals and other suggestions for policy change to the annual budgetary process.

Operating with no constituency other than the President BOB provided objective staff assistance over time. Its biases were those of professional careerists in public service. Bureau officials developed a skeptical attitude toward other participants in the policy process-bureaucrats, congressmen and their staffs, and pressure group representatives-and they routinely challenged all suggestions and ideas in the context of their conception of the President's program goals. The Bureau did not, however, serve as a source of information. It was an institutional screen through which all kinds of information and advice was filtered and assayed in terms of its value to the President and his program.

The changes instituted under Reorganization Plan No. 2 will undoubtedly affect the central role of $B O B$ in policy formulation. The emphasis in the new OMB is more on management than on policy development. The Domestic Council and its staff will presumably assume many of the functions formerly performed by BOB. This shift occurred in the realm of national security policy in 1947. It is too soon to determine if OMB's domestic policy role will parallel the rather limited one that it has played with respect to national security matters. Certainly the domestic policy format will be different. Decisions which Budget Bureau officials and White House staff members formerly made apart from department heads will presumably be made in a forum that includes them as principal participants. OMB will be involved

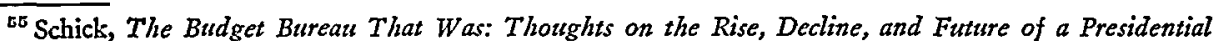
Agency, 35 Law \& Contemp. Prob. 519 (1970).

七o See Neustadt, Presidency and Legislation: Planning the President's Program, supra note I3; Neustadt, Presidency and Legislation: The Growth of Central Clearance, stupra note I3; Maas, In Accord with the Program of the President, in 4 PuBLIc Policy 79 (1953).
} 
but as a supportive staff whose major concern is with costs and with implementation. However well these changes work in practice, it is their clear objective to reduce the significance of the budget staff in presidential policy formulation and to utilize it more extensively as a device for coordinating and rationalizing the implementation of policy. Given the great value of $B O B$ to Presidents since Roosevelt it is, in my judgment, questionable whether the revision of its mission and the consequent separation of policy formulation from implementation will "enable the President to have more facts and better options at his disposal when he makes his decisions." It is doubtful if structured enforcement of the politics-administration dichotomy will endure and, if it does survive, whether presidential policy leadership will be enhanced rather than weakened. ${ }^{58}$

\section{E. The Inner Circle and White House Staff Advisers}

The absence of formal institutional support for the President in Congress, the fragmented parochialism of the bureaucracy, and the lack of an integrating party structure grounded in an ideology combine to make the task of leadership in policy formulation one of bargaining and manipulation. As Neustadt has so aptly stated, "presidential power is the power to persuade." leadership, modern Presidents have depended heavily on the group of friends, counsellors, secretaries, and other aides who constitute the White House Staff and on an informal inner circle of close associates and confidants. These two sets of advisers are continuously and directly involved with him in the formulation of policy. They have some overlapping members and their composition and operational pattern varies between administrations and over time within a single presidency.

Inner circles, which have also been referred to as "kitchen cabinets," "the invisible presidency," and similar terms, tend to be comprised of a few key White House staff members, one or two Cabinet members who enjoy the special confidence of the President, and occasionally a few personal friends of the President. ${ }^{00}$ There is a tendency to attribute great power to these intimate presidential advisers and they no doubt have exercised considerable (but indeterminate) influence over recent Presidents. For example, John Foster Dulles and Sherman Adams apparently predominated over all other advisers to President Eisenhower for the first several years of his presidency. The intimate personal and intellectual relationship between President Kennedy and his brother Robert is well known. And President Johnson placed great reliance on two of his Cabinet members, Secretaries Rusk and McNamara. Although interaction between the President and his informal inner circle is a central feature of policy formulation, it is necessary to guard against overemphasizing this

\footnotetext{
ธr Testimony of Dwight Ink, Assistant Director of the Budget, Reorganization Plan No. 2, supra note $\mathrm{I}$, at 89 .

${ }^{88}$ Cf. Carey, Reorganization Plan No. 2: Remarks, stspra note 54.

${ }^{50}$ R. Neustadt, supta note 7, at 32. See also E. Herrung, Presidential Leadership 24 (I940).

${ }^{\circ 0}$ Cf. Seligman, Presidential Leadership: The Inner Circle and Institutionalization, supra note $2 ; \mathrm{L}$. Koenig, The Invisible Presidenct (1960); P. Anderson, The Presidents' Men (rg68).
} 
phenomenon. There exists a collective presidential decision-making process that is not so much the work of a few individuals as the organized effort of many groups including the inner circle, the White House staff, OMB, and a host of presidential advisory committees. ${ }^{11}$ Furthermore, national policy-making may center in the presidency, but it involves a considerable number of political elites in different policy areas. These elites, which overlap only occasionally, participate actively with the presidency in shaping national policy. ${ }^{62}$

The inner circle provides the President with broad gauge advice on critical policy choices that is unrestrained by departmental, agency, or pressure group interests. It is held together by a mutual bond: the President's need for advisers who share his values and goals but who can broaden his perspective and the advisers' capacity and desire to meet that need. Membership in the inner circle is prestigious (despite Brownlow's plea for men with "a passion for anonymity") but it may be shortlived. The tasks that its members perform are demanding, and the President's needs and preferences change. According to Seligman, inner circle members function as "buffers," "catalysts," "liaison men," "fixers," "needlers," "communications experts," "policy advisers," and "sometime ideologists." 33 Its members may be selected because of their ability to perform tasks for which the President is unsuited. In this respect, the inner circle complements the President's personality. It compensates for his limitations. $^{64}$

The White House staff, which usually includes some inner circle members, is larger and more formalized. The President enjoys great freedom in setting up his office and selecting his staff, but its functions are fairly well established. Its primary job is to furnish the President with sufficient information and analysis to permit him to make decisions with an awareness of the available alternatives and their probable consequences. The specific tasks of the White House staff include press relations and communications, speechwriting, congressional liaison, pressure group and general public liaison, management of the President's schedule, and policy advice and counsel.

The management of press relations and communications is crucial to building and maintaining a favorable presidential image. The persons who perform these tasks, however, seldom manage to exert influence on major policy decisions. Their advice relates to tactical rather than strategic matters. Speech writers are also involved in presidential communications. Their role affords them the opportunity to exert sorne influence on substantive policy decisions, but only to the extent that the President has confidence in the judgment of the individual speech writer. For in-

\footnotetext{
${ }^{01}$ Cf. J. Burns, supra note 2, at 152-53; Seligman, Developments in the Presidency, supra note 2, at 707.

See Thomas, Bureaucratic-Congressional Interaction and the Politics of Education, 2 J. CoMr. AD. 52 (1970); Cronin, The Presidency and Education, Phi DelTa Kappan, Feb. 1968, at 295.

${ }^{3}$ Seligman, Presidential Leadership: The Inner Circle and Institutionalization, supra note 2, at 4 I2I3.

ot Seligman, Developments in the Presidency, supra note 2, at 7 ro.
} 
stance, Theodore Sorensen was one of President Kennedy's principal speech writers. His style, tone, and ideas merged with those of his chief so that they were often indistinguishable. On the other hand, the identity of President Nixon's wordsmiths is virtually unknown. They remain anonymous White House artisans who mold presidential addresses to specifications determined by their superiors.

Presidential liaison with Congress and with pressure groups is a White House staff function of twofold importance. It shapes the scope and content of input from Congress and pressure groups to the policy-making process and it affects the level of support for the President's policy goals. Failure to involve congressional leaders adequately at a sufficiently early stage can spell the defeat of the President's legislative program. As a practical political matter, congressional sentiment must be assessed and congressional leaders consulted in determining the administration's policy agenda. The operating responsibilities of the congressional liaison staff include presenting the administration's position on legislation to individual congressmen, coordinating and directing the administration's legislative program on Capitol Hill, gathering information, including congressional sentiment, analyzing legislative issues, assessing the potential impact of presidential statements and actions, and performing auxiliary services for members of Congress. ${ }^{65}$ Under Presidents Eisenhower and Nixon congressional liaison has been a line operation somewhat removed from direct access to the Chief Executive. Their liaison staff directors, Wilton Persons and William Timmons, did not enjoy direct access to them. ${ }^{60}$ The policy impact of the liaison staff under these circumstances has come from its assessments of probable congressional opinion and actions. Under Presidents Kennedy and Johnson, congressional liaison occupied a more central position in the White House staff. With Lawrence O'Brien, a skilled political tactician, directing the lobbying staff, congressional relations were significantly upgraded, although it took O'Brien and his team some time to master their work. Both Democratic Presidents worked directly with O'Brien in shaping the content of their legislative programs as well as in developing legislative strategy. While all Presidents are dependent on their liaison staffs to shepherd legislation through Congress, the role of that staff in policymaking varies substantially. ${ }^{67}$ All presidential lobbyists are agents, salesmen, and contact men. They can become advisers and counsellors if the President wishes.

Until the Nixon Administration, liaison with politically important interests was handled by the congressional relations staff and through the practice of assigning primary responsibility for liaison with groups in specific policy areas to presidential assistants. Access to the White House was generally channeled through these individual contact men who acted as brokers between the presidency and the pressure groups.

\footnotetext{
${ }^{65}$ For an excellent description of President Nixon's congressional liaison operation see Bonafede \& Glass, White House Report/Nixon Deals Cautiously with Hostile Congress, Nar'L J., June 27, 1970, at 1353.

${ }^{60}$ In November, I970 President Nixon appointed former Congressman Clark McGregor as a counsellor with responsibility for congressional relations. McGregor's role and relationship to the President is yet to be established.

${ }^{a 7}$ Cf. A. Holtzman, Legistattve Liaison: Executive Leadership in Congress (i970).
} 
Outside groups knew whom to see if they wished to make a presentation of their views. The assistants who acted as contacts performed these tasks in addition to their other duties. They did not formally coordinate information gathering or the rendition of advice, but were available to groups seeking access. In varying degrees and ways, they filtered the input to the President from external sources. President Nixon, in keeping with his preference for formalizing staffing arrangements, assigned responsibility for contact with organized constituencies to a separate staff. ${ }^{68}$ The outside liaison staff acts as a broker between pressure groups and administration policymakers. The lodging of this responsibility in a special staft is an attempt to improve the scope and content of informational input and to more effectively convert the resources of private interests into support for the President. It has the advantage, from the presidential perspective, of systematizing what previously was a random process. Its disadvantages are not yet clear, but one possible difficulty may stem from the inability of a small liaison staff to develop sufficient familiarity with all policy sectors to be able to deal selectively and effectively with them. The liaison staff may simply become a crew of messenger-errand boys with no function other than to receive and direct communications and to perform special chores such as organizing meetings and checking out presidential appointments. An outside liaison staff with no recognized policy impact could become a liability if pressure groups perceived them as buffers between themselves and the real policy-makers. As with congressional liaison, the President must rely on the White House staff to manage relations with organized constituencies. They have great potential value to him as sources of political leverage but they can also be sources of frustration. Dealing effectively with pressure groups requires a skill and tact that gives them a sense of efficacious involvement in policy formulation. The most appropriate approach to this staff function is not yet apparent.

The management of the President's time is another vital task of the White House staff. There are two dimensions to this function: the screening, condensation, and digesting of information that reaches the President and the control of his schedule. Obviously, time is a most precious presidential resource. No President can read all the memoranda, reports, newspapers, and other printed matter that he should to be ideally well-informed. Therefore, he must attempt to minimize the costs of his ignorance. $^{69}$ The White House staff performs this task in accordance with presidential reading habits and tastes, but regardless of its directives it necessarily exercises substantial discretion over what the President reads. There is an inescapable policy impact in this staff function that should be recognized even though it cannot be controlled.

The staff members who manage the President's schedule perform an ancient

\footnotetext{
${ }^{\circ 8}$ See Bonafede, Men Belind Nixon/Charles W. Colson: President's Liaison with the Outside World, Nat'i J., Aug. 8, 1970, at I689.

${ }^{\circ 0}$ Cf. Downs, Why the Governmental Budget is Too Small in a Democracy, r2 WorLd Pou. 54I (r960); A. Downs, AN Econome Theory of Democracy (1957).
} 
political task, that of doorkeeper. Since the beginnings of organized government those who guarded the ruler's door have exercised substantial influence and power. Henry Fairlie describes the White House as "pre-eminently a staff of competing doorkeepers," and he argues that the medieval office of chamberlain still exists. ${ }^{70}$ The President depends on his schedule makers to reserve his time for those persons and activities which are politically beneficial and to protect him from unnecessary wasting of time. The policy preferences of the President's doorkeepers can determine who sees him and thus, to a degree, exerts an influence on his decisions. To minimize the power potential that inheres in their "chamberlains" Presidents have tended to select men whose personal loyalty is unquestioned and whose policy interests are either so limited as to pose no problem or closely identical to those of the President, such as President Nixon's assistant, H. R. Haldeman.

The members of the White House staff also provide the President with policy advice and counsel. (Those who particularly "have his ear" become, by definition, members of the inner circle.) White House staff advisers fall into two general categories. First, there are the experts and intellectuals whose skills, knowledge, and experience make them valuable as idea generators and as evaluators of policy alternatives. Their professional or academic perspectives complement the political outlook of the President. In the early years of the Nixon Administration, Henry Kissinger in national security policy, Daniel Patrick Moynihan in domestic affairs, and Arthur Burns in economic policy furnished this type of advice. The second basic category of White House advisers includes close political associates and personal friends of the President. These are truly the President's men whose main value lies in their ability to perceive an issue or situation in terms of its effect on the President and his political objectives. Their advice and counsel is political and personal. In the Nixon administration, John Erlichman, and Robert Finch, after his departure from HEW, exemplify the close political-personal adviser. Such advice is necessary and essential to a President, but hardly sufficient. It must be combined with expert and professional advice within the White House and with a wide array of external advice and information.

White House staff advisers are a mobile and transient group. Their ranks seldom hold firm as most Presidents move through several sets of advisers in the course of their administrations. In part this is due to the expendability of presidential staffers who not infrequently drop out when policies they have espoused fail or lose favor. It also stems from changing policy goals and situational factors which alter presidential staffing requirements.

\section{F. Presidential Advisory Committees}

The formulation of policy in the presidency and the executive branch also involves extensive utilization of advisory committees. A General Accounting Office

\footnotetext{
${ }^{70}$ Fairlie, Thoughts on the Presidency, The PuBuic InTERest, Fall 1967 , at 37.
} 
survey, conducted in late 1969 , revealed the existence of 1,573 boards, committees, commissions, panels, councils, conferences, task forces, and other advisory groups. ${ }^{71}$ The survey identified Ig8 "presidential committees," that were so designated when one or more of their members was appointed by the President. These presidential groups are created by statute, executive order, or less formal directive. Their manifest task is to advise and make recommendations, but they perform other functions as well. An analysis of the full range and activity of presidential advisory committees is beyond the scope of this paper. I will limit my discussion to the most salient aspects of those groups which have played a prominent role in presidential policy formulation: public commissions, White House task forces, and White House conferences, all of which operate for a limited time period, and permanent advisory bodies, such as the CEA and the President's Science Advisory Committee (PSAC), that are lodged in the Executive Office of the President.

Modern Presidents have used short-term advisory bodies for the study of specific problems or issues. The end product of these groups is usually a report and a set of recommendations for action. Public commissions are the most well-known temporary advisory committees. ${ }^{72}$ Presidents employ commissions for various purposes. The establishment of a commission is a safe response to a serious situation or problem. It dramatizes the President's concern and his desire to obtain expert information and advice. The unstated presumption is that presidential action will follow the report and recommendations of the commission. Although the commission may prove to be an important source of advice, its immediate function is to reassure the public, ease tensions, and alleviate pressures on the President. The Warren Commission, the Kerner Commission, and the Scranton Commission performed this function for Presidents Johnson and Nixon. Their proposals, however, did not serve as major sources of policy initiatives. Commissions have also been used to study less salient but persistent problems such as housing (the Kaiser Committee of r96768 ) and executive organization (the Ash Commission of rg69-7x). These groups, although less publicized, tend to be more able to perform fact-finding and analytical activities that will generate viable policy suggestions for the President.

Most commissions, being public bodies, are necessarily broadly representative. This means that all relevant functional constituencies are included in the membership, a condition that has effects on the work of the commission. On the one hand, it may lead to a thorough airing in a highly visible forum of the central policy issues involved. On the other hand, it may result in a blurring of critical differences of opinion because of pressures to produce a consensual document. In most cases the representative character of presidential commissions contributes to their failure to serve as important sources of new ideas. (The r97o report of the Commission on

\footnotetext{
${ }^{71}$ Presidential Advisory Committees, supra note $\mathrm{x}$, at 5.

${ }^{73}$ See F. Popper, The Presment's Commissions (I970); Drew, On Giving Oneself a Hotfoot: Government by Commission, Atzantic, May, I968, at 45; Bell, Government by Commission, THe Public INTEREST, Spring, Ig66, at 3 .
} 
Obscenity and Pornography is a notable exception, although its proposals were publicly rejected by the President.) As one critic of the Kerner Commission observed, its purpose was "not so much to develop innovative solutions as to legitimize existing untried solutions."73

Sometimes a presidential commission can prove quite embarrassing to the Chief Executive. President Johnson chose largely to ignore the Kerner report's sweeping proposals for new and expanded domestic programs. They were strikingly incompatible with a tight federal budget and with the proud claims of accomplishment for the Great Society. Two years later, in 1970, President Nixon's alleged lack of leadership was a major finding of the Scranton Commission's report on campus disorders. Although Nixon's response to the report was moderate in tone, other members of his Administration rushed to attack the report and castigate its authors. The report of the commission on obscenity and pornography-a group appointed by President Johnson-received open criticism from Nixon, who used it to inject an anti-smut dimension into the 1970 congressional election campaign.

Because the use of public study commissions entails substantial costs that may outweigh their potential benefits, Presidents since John F. Kennedy have also sought information through the employment of other devices such as task forces. ${ }^{74}$ These flexible, informal groups have been used to collate a wide range of thinking and generate new proposals in specific policy areas. Presidents Nixon and Kennedy used them as vehicles for easing the transition to their administrations. President Johnson relied upon them as primary sources of ideas for his legislative program. The Johnson task forces were more systematically operated than Kennedy's or Nixon's have been to date. In all three administrations, however, task force personnel and procedures have contrasted sharply with public commissions and with permanent advisory councils. A primary rationale for task forces is that they are not confined by the narrow institutional perspectives of the bureaucracy and Congress or by the parochial concerns of clientele groups. Rather, they permit the President to call upon people outside the government with a proper balance between imagination and practical political considerations for advice in the form of brief appraisals and tentative suggestions. Task force members tend to be university and foundation based experts who have some knowledge of and experience with the government. They are not necessarily representative of all relevant constituencies.

Task forces work with limited staff assistance. Unlike commissions, they do not produce long, documented analyses. Their reports usually are not published and they have no official status. The President may keep the task reports confidential or make all or parts of them public. The ideas contained in them can be accepted or rejected with limited risk of political embarrassment.

\footnotetext{
${ }^{73}$ G. Marx, Report of the National Commission: The Analysis of Disorder or Disorderly Analysis? (paper presented at the annual meeting of the American Political Science Association, Waslington, D.C., 1968).

"See Thomas \& Wolman, supra note 9; Glazer, On Task Forcing, THE Pubuic INTERest, Spring, I969, at 40 .
} 
The limitations of task forces arise from the very informality and flexibility that constitute their greatest value to the President. They cannot carry as much weight as more formalized and publicized bodies. Their reports tend to be quite tentative and speculative and are unlikely to stand alone as the basis for new policies. They require supportive recommendations and additional studies by other groups in the bureaucracy and the Executive Office of the President. To the extent that task force reports are kept secret, as they were in the Johnson Administration, they engender resentment in the agencies, on Capitol Hill, and in clientele groups. But if the reports are made public, pressure tends to build for the President to react to the proposals regardless of how tentative they may be. Task forces also risk becoming routinized if they are used too extensively. Their success may lead to the destruction of their informal, flexible character. Task forces are a useful but limited means of obtaining the experience, information, and ideas from outside the government.

White House conferences have been held on occasion to draw attention to a specific problem by bringing together a group of distinguished citizens for a public discussion under presidential auspices. In the past decade conferences have been held on such subjects as education, civil rights, and international cooperation. The principal function of such gatherings is support-building through publicity. White House conferences have been criticized as explorations of "the lowest common denominators of their subjects." Th5 have been lauded as manifestations of "meaningful dialogue between citizen and government official." being organized into numerous committees and operating with temporary staff assistance, the conferences are not likely to be of great value as sources of new ideas and information. Their principal utility lies, by virtue of their nature, in the base that they potentially provide among professionals, political leaders, and relevant constituencies for presidential leadership in meeting the problems at issue. There are always risks in staging White House conferences. At least some of the notables who attend are likely to have ideas that are quite at variance with the values and goals of the President and his administration. These participants may be able to make the conference move in unintended and embarrassing directions. Another difficulty that the conferences pose is the generation of expectations that cannot be met. While a good many participants are not so naive as to regard a conference as the solution to the problem, the affected sectors of the public and even some participants tend to assume that there is a presidential commitment to action. In any case, although White House conferences can attract and build support and impart legitimacy to new policy initiatives, they have substantial limitations.

While modern Presidents have had varying success in utilizing temporary advisory groups, they have generally found two permanent advisory councils with supportive staffs, CEA and PSAC, to be of substantial value in the formulation of national

\footnotetext{
${ }^{75}$ Fairlie, Book Review, N.Y. Times, Nov. 27, I966, § VII (Review of Books), at 32, 34 .

${ }^{70}$ Clemens, Letter to the Editor, N.Y. Trmes, Dec. 18, 1966, $\$$ VII (Review of Books), at I5.
} 
economic and science policies.77 These two bodies are an integral part of the Executive Office of the President and thus represent the most extensive formalization of presidential advisory committees. Both possess independent staffs, but their structure and operating methods are quite dissimilar. The CEA consists of three distinguished economists who devote full time to their task and are supported by a professional staff. The CEA studies economic trends, analyzes macroeconomic policy alternatives, and examines the economic impact of substantive policy proposals in areas such as housing, welfare, and defense. It furnishes the President with sophisticated analysis that provides a rationale for presidential decisions and is a major conduit for funneling new economic ideas to the President. In the Kennedy and Johnson Administrations the CEA often competed with the Treasury and the Federal Reserve Board in shaping economic policy. Under President Johnson the Council became involved as a major participant in certain policy sectors such as housing. It moved beyond a purely advisory to a policy-making role. Presidents Eisenhower and Nixon tended to rely somewhat less on the CEA for basic policy suggestions and used it more as an analytical resource. The CEA's value to presidential staffing lies in its professional character and in the absence of any formal ties to a clientele group (other than the academically based American Economic Association).

The science advisory structure is also highly professionalized, but is somewhat more complex than the CEA operation. PSAC consists of seventeen persons, most of them distinguished academicians, and is chaired by the Special Assistant to the President for Science and Technology. The special assistant, who is the only fulltime member of PSAC, also functions as director of the Office of Science and Technology (OST) and chairman of the Federal Council for Science and Technology, an interagency coordinating committee. PSAC conducts much of its business through panels consisting of one or two of its members plus additional personnel. These panels examine specific subjects and problems and file reports and recommendations. OST furnishes staff assistance to the PSAC panels, evaluates scientific research programs, and assists OMB in the development of science agency budgets. Since the establishment of OST in 1962, it along with PSAC and the special assistant have advised Presidents on such topics as the nuclear test ban treaty, the space program, domestic uses of science, and the development and support of scientific research and education. The science advisory system is geared to enable a non-scientist President to make decisions involving the support and use of science that are compatible with his political, social, and economic goals. In an increasingly complex technological environment this is an advisory mechanism of great importance. Presidents since Eisenhower have relied heavily on it to help them shape science policy. According

\footnotetext{
${ }^{77}$ For an analysis of the CEA see E. Flash, Economac Advice and Presidential Lendership: The CounciL of Econome Advisers ( 1965 ). The science advisory system is carefully described and analyzed in M. Reagan, Sctence and the Federat Patron (I969).
} 
to Michael Reagan, the science advisory system has worked to the advantage of both the scientific and political estates. ${ }^{78}$

Thus far I have not mentioned the myriad of committees and other groups that advise the President, Cabinet members, and lesser officials. These include two basic types, interagency committees and public advisory committees. The interagency committee is primarily a coordinating device and is used mainly to monitor policy and program implementation. Occasionally in the Kennedy and Johnson Administrations, interagency task forces were assigned responsibility to develop presidential legislative proposals. Interagency groups are apparently necessary to overcome the structural dispersion of the federal bureaucracy. They have had varying degrees of success depending, at least in part, on the rank and prestige of the chairman. In testimony before the Monagahan subcommittee, William Carey, a long-time budget bureau official, cited the Federal Interagency Council on Education (FICE) as an example of an ineffectual group. FICE, which an Assistant Secretary of HEW chaired, "never did get around to giving advice to the President."79 On the other hand, Carey observed that the Federal Council on Marine Resources and Engineering Development, which the Vice President chaired, was highly successful.

Public advisory committees are a pervasive phenomenon in national politics. They can provide a steady flow of new ideas to the President and members of the administration and in so doing improve the quality and widen the range of policy options that are open. They can also serve to broaden the participation of individuals and groups in the processes of policy formulation thus improving communication between the government and the public and increasing popular support for various programs. But advisory committees are subject to limitations if not abuse. Agencies tend to use them as crutches or shields. Advisory committee members may be coopted to support narrow bureaucratic rather than broader presidential and public values. It is also possible that committees may attempt to exercise control over the agencies. To the extent that they succeed democratic responsibility to the public is blunted.80

The most troublesome problem that advisory committees present the President is not the lack of information and advice, nor the absence of effective means to obtain it. Rather, it is the difficulty of organizing and using the advisory system effectively. What the President does not and cannot know is immeasurable. Most of the proposals, recommendations, and reports of the numerous committees that are advisory to him never reach the President. As William Carey told the congressional subcommittee investigating the matter:

\footnotetext{
${ }^{78}$ M. REAGAN, supra note 77. Reagan believes that the government-science relationship is tenuous because of the continuing threat that use of the government's financial leverage to direct science to the achievement of utilitarian goals will destroy the autonomy of basic science. Id. at 3 I7-Ig.

${ }^{70}$ Presidential Advisory Committees, supra note $\mathrm{I}$, at $\mathrm{I} 6 \mathrm{r}$.

${ }^{80}$ For a discussion of policy advisers in the area of education, see Cronin \& Thomas, Educational Policy Advisers and the Great Society, 18 Public Policy 659 (1970); Cronin \& Thomas, Participant Perspectives on Federal Advisory Processes, forthcoming in ScIence.
} 
... Government is getting a great deal of advice, and some information, from the legions of advisory bodies which it creates. I am much less clear on what happens to the advice, or who is listening. I do know that very little of the advice emanating from most advisory bodies ever seeps through to the President himself. Most of it is lost through evaporation, some of it leaks out on staff advisers to the President, and no one can say with certainty how much of it feeds into policy decisions. There is no catch basin to filter and synthesize committee advice and recycle it through the executive branch system. ${ }^{81}$

The need for evaluation and analysis of information on a systematic basis has been long recognized and is at the heart of the rationale for Reorganization Plan No. 2 of 1970. There have been some successful ventures in this direction, such as the CEA and the science advisory system, but they were not comprehensive. The policy analysis performed by the former Bureau of the Budget, as important and vital to presidential leadership and planning as it was, did not provide integrative and synthesizing functions at a level of analysis that would solve the problems Carey describes. Perhaps the new Domestic Council will do so.

Advisory committees of all types are indispensible instruments of presidential policy leadership. However, they have been used indiscriminately in recent years with the result that their credibility has been damaged and their potential value reduced. Furthermore, their findings and recommendations have not always been systematically analyzed or regularly used as the basis for further policy development. No doubt Presidents will continue to employ them, but a more realistic appraisal of their capabilities is in order.

\section{III}

\section{The Advisory Function: A Summary}

It has been asserted on more than one occasion, both by former participants in the work of the presidency and by students of it, that much of what happens escapes the attention of the President. This is not at all surprising given the complexity of governmental operations, yet there remains the need for effective presidential leadership in the making of basic policy decisions. That leadership is heavily dependent on the advice and information that the President receives. To a considerable extent the President's office and powers are defined in the Constitution and by statute, he must function as head of one of three equal branches of government, Congress and established customs have imposed numerous duties upon him, and as the nation's major political leader he is expected to respond to the demands of partisans and established constituencies. In meeting the many expectations that surround their various roles, modern Presidents have found it convenient and necessary to utilize some basic sources of advice and information that inhere in the institution and the situation in which they must operate.

\footnotetext{
${ }^{81}$ Presidential Advisory Committees, supra note $\mathrm{I}$, at $\mathrm{I} 6 \mathrm{r}$.
} 
In this paper I have examined some of the principal advisory mechanisms that Presidents have employed in the process of policy formulation. The Cabinet and its committees, the top echelon councils for national security and domestic policy, the Office of Management and Budget, the White House staff and its inner circle, and the permanent and temporary presidential advisory committees all carry accompanying benefits and costs. For example, the Cabinet as the symbolic embodiment of the representative character of the administration appears ideal for building support and developing consensus when used as a policy-making body. But it is so severely hampered by the fragmentation inherent in the pluralistic basis of departmentalization that frustration often results when Presidents try to use it. Or, when various types of advisory committees are employed to tap vitally needed external sources of information, they may prove unmanageable or even embarrassing to the President. Or, devices designed to provide systematic identification, analysis, and management of issues and problems, such as the NSC system, may be instituted at the expense of policy rigidity that limits the capacity for flexible response in emergencies.

The use of many advisory mechanisms-the White House staff and its inner circle, the OMB, and some type of NSC system-is inescapable and each President must adapt them to his personal administrative and leadership styles and to his policy objectives. The use of other mechanisms-the Cabinet and its committees and presidential advisory committees-is much more discretionary. How Presidents employ them is likely to vary between administrations according to a rough costbenefit calculus that also incorporates elements of style and political goals.

Generally, it appears that Democratic Presidents have tended to prefer a less formalized, more open advisory system characterized by relatively easy access of individuals and groups to the President, a heavy flow to the President of reports, memoranda, and other written material that has only been partially refined or screened, an absence of strict functional specialization within the system, and a pragmatic flexibility that is adaptable to emergencies but poorly suited to any kind of long-range planning. Conversely, Republican Presidents have tended to organize their advisory systems more formally and elaborately. Their arrangements have featured greater reliance on the Cabinet as an advisory and decisional body, more finely prescribed procedures and routines for obtaining and processing information, more careful management of the President's time through controlled access to him and highly selective filtration of the flow of paper, an insistence on functional separation of intelligence tasks, and strong emphasis on long-range planning seemingly at the expense of adaptability to emergency situations. The greater propensity of most Democratic Presidents to innovate in domestic policy also appears to be associated with their preference for more open staffing arrangements. The Republican Presidents' preference for structural formalism and prescribed routines is, however, at its strongest in the realm of national security policy where there is much less partisan difference of opinion over policy alternatives. This suggests that the partisan 
factor is an independent determinant of staffing arrangements for presidential policy formulation.

Regardless of party affliation, the inclination to develop new policies, and personal operating style, the President needs substantial assistance in obtaining and utilizing advice and information. Successful presidential policy leadership requires that the President's goals be sufficiently well defined that governmental performance can be directed and measured according to the standards that the goals provide. The refinement of presidential policy preferences is not an easy task, for the presidency is the strategic focal point of pressures and demands that emanate from independently powerful elites that function in the numerous policy areas. ${ }^{82}$ The President acts as a broker and mediator between these competing and usually non-overlapping elites. He can provide leadership and direction in those policy areas that he regards as important, but only if he has secured the needed intelligence.

Unfortunately, there is no specific formula for an effective advisory and information system. As President Nixon has so appropriately observed:

There is no textbook prescription for organizing the machinery of policy making, and no procedural formula for making wise decisions. The policies of this Administration will be judged on their results, not on how methodically they were made. ${ }^{83}$

Perhaps the most that can be stipulated is that presidential advice and information should be as wide ranging as possible and that it should encompass diverse social, economic, and political perspectives. The advisory system should be structured so that the President is not isolated, yet he must be protected from fatuous incursions on his time and energy. At key points close to the President there should be situated two sets of advisers, one with unquestioning personal loyalty to him and the other with broader professional and political loyalties. Within these limits, the President may use whatever combination of advisers and advisory mechanisms he wishes. The system that he develops will always be characterized by nagging uncertainties as well as promising potential. Consequently there needs to be continuous analysis and evalution of the presidency and its intelligence system. Yet the basic pattern is set and, even with structural shifts such as Reorganization Plan No. 2, is likely to undergo only marginal adjustments. Ultimately it may well be that muddling through is the most that we can hope for. If so, the challenge that remains is still demanding: to manage the muddling so as to produce satisfactory, if not optimal presidential policy leadership.

\footnotetext{
${ }^{82}$ Cf. T. Cronin, The Textbooi Presidency and Political Science 34-36 (paper delivered at the annual meeting of the American Political Science Association, Los Angeles, Calif., Sept. 1970).

${ }^{88}$ Report by President Nixon, supra note 37 , at H929.
} 